\title{
WHO SPEAKS FOR HUME: HUME'S PRESENCE IN THE DIALOGUES CONCERNING NATURAL RELIGION
}

\begin{abstract}
One of the reasons for many different and even opposing interpretations of Hume's Dialogues Concerning Natural Religion is the absence of consensus concerning the question of which character in the Dialogues represents Hume. In this paper I argue that taking Philo to be his primary spokesperson provides us with the most consistent reading of the whole work and helps us better understand Hume's religious viewpoint. I first stress the specific dialogue form of Hume's work, which requires us to take into account literary tools such as irony and double-talk when interpreting it. From there I proceed to show why I believe that my hypothesis is better supported than the other two main hypotheses concerning Hume's presence in the Dialogues, the first one being that Cleanthes represents Hume and the other one that none of the characters consistently speaks for Hume but rather that the whole structure of the work does that. Although there is both textual and historical evidence which suggests that Hume favoured Cleanthes, I show that his opinions deviate from Hume's well-known views on important subjects such as scepticism, morality and Christianity, while Philo's opinions on these subjects agree with Hume's almost verbatim. The second hypothesis is proven to be wrong by the fact that Philo actually consistently defends Hume's opinions. Finally, I argue that Philo's understanding of true religion as a philosophical position devoid of any religious import agrees with Hume's religious scepticism.
\end{abstract}

Keywords: David Hume, philosophical dialogue, true religion, religious scepticism

\section{Introduction}

The question of which character in the Dialogues concerning Natural Religion represents Hume's own views, and whether this role should be assigned to any one of them, has been widely debated, but still remains undecided. This question is important because identifying Hume's spokesperson in the Dialogues could bring us closer to understanding his intentions and goals in writing this work and, in connection to this and maybe more importantly, it could lead us to a better understanding of his own views on religion. It

* I would like to thank an anonymous referee for helpful comments on the previous version of this paper. 
is worthy of mention that "[i]n the totality of his work Hume wrote more about religion than about any other single philosophical subject." (Gaskin 1988 , 1) Probably better known than this is the fact that during his life he was notorious for his attitude towards religion, which twice prevented him from obtaining an academic position and almost got him excommunicated from the Church of Scotland. He certainly approached the subject polemically and from many different angles. In both his documented correspondence and in his writings he was highly critical of and even hostile to organised religion, in his Natural History of Religion he attempted to explain the causes of religious beliefs exclusively in terms of psychological and sociological factors and throughout his various philosophical writings he contributed to many of the central questions in the philosophy of religion including the reliability of miracles, the immateriality and immortality of the soul, various arguments for God's existence, God's natural and moral attributes, the morality of suicide and others. Although none of his arguments is particularly favourable to the religious point of view we are still finding it difficult to decide what they amount to and how Hume's position concerning religious beliefs should best be characterised.

We could plausibly understand him to be a deist, an atheist, or a sceptic. There are two main reasons for such differing interpretations. The first reason, which I shall discuss only briefly, is that Hume, like every other person engaging critically with religion in the $18^{\text {th }}$ century, had to be very careful about what he was saying and writing in order to avoid religious persecution. He couldn't have voiced some opinions even if he had held them for fear of excommunication, imprisonment or worse. He obviously, and probably intentionally, wasn't careful enough, which earned him the reputation of an infidel, but it is still true that "in his published writings he had always refrained from marshalling all of his skeptical challenges at once, thereby appearing to leave some kind of refuge for the devout." (Rasmussen 2018, 188) In his Treatise on Human Nature he attacks the causal maxim and the idea of demonstrating the existence of anything a priori, thereby undermining the cosmological and the ontological argument for God's existence, but apparently leaving room for the teleological argument, i.e. the argument from design. ${ }^{1}$ In his first Enquiry he famously attacks this argument as well, but almost completely

1 Hume certainly took advantage of this circumstance when he defended himself from the accusations of maintaining atheism in the Treatise in his anonymous $A$ Letter from a Gentleman to His Friend in Edinburgh. He replied to his accuser by claiming that the fact that he had denied the principle that whatever begins to exist must have a cause of its existence, thereby undermining Clarke's cosmological argument for God's existence, doesn't mean that he had denied the success of any other argument for God's existence and he specifically mentioned the teleological argument as one which he, apparently, endorsed: "Wherever I see Order, I infer from Experience that there, there hath been Design and Contrivance. And the same Principle which leads me into this Inference, when I contemplate a Building, regular and beautiful in its whole Frame and Structure; the same Principle obliges me to infer an infinitely perfect Architect, from the infinite Art and Contrivance which is displayed in the whole Fabric of the Universe." (LG 158) 
avoids the talk of moral and political effects of religion, and the same is true of all his writings on religion published during his lifetime. However, in the posthumously published Dialogues concerning Natural Religion, his greatest and most influential work in the philosophy of religion, Hume carries out the most comprehensive attack on prominent religious doctrines of his time, leaving barely any claim of religious significance intact. Since he knew the Dialogues was going to be published posthumously, it might seem that he could have expressed himself more freely there than in any of his other works. However, both how the Dialogues is structured and the way some of its parts were written suggest that Hume was concerned for his reputation even after his death and that he took great care to rather carefully and covertly express the most controversial aspects of this work. ${ }^{2}$

The second reason hindering clearer understanding of Hume's religious stance is linked to the first one but specifically concerns the Dialogues. The main problem with understanding this work consists in there being many different and even opposing interpretations of it. Since Hume's writing is as clear and precise there as in any of his other works I think this is at least in part a consequence of different interpreters taking different characters to speak for Hume. This was made possible by the infamously ambiguous last part of the Dialogues. Had Hume never written it or had he written something like an epilogue to and consistent with the previous eleven parts, I believe that the vast majority of interpreters undoubtedly would have agreed that the sceptic Philo represented his opinions. However, the actual Part 12 of the Dialogues contains the so-called "Philo's reversal" in which this character, who previously provided us with what is probably the most comprehensive and powerful critique of the argument from design, professes his "veneration for true religion" and apparently endorses the same argument he had been vehemently criticising thus far. This turn of events at the end of the Dialogues confused the interpreters so much that some of them thought that Hume concluded that no religious belief was justifiable while others maintained that he not only accepted the justifiability of some religious beliefs but that he also established that the belief in intelligent design was the most reasonable one. For this reason, I take this to be the main point from which all the different interpretations of Hume's position concerning the existence and nature of God proceeded from.

In what follows I shall argue that, despite these difficulties, we should still take Philo to be Hume's main representative in the Dialogues. I will offer reasons as to why I think this hypothesis fares better than the two other hypotheses which have enjoyed some support in both earlier and recent times. My main task, however, will be to show why Philo's apparent change of heart at the end of the Dialogues poses no real problem for the interpretation I am defending. This will require me to consider a few different factors that should be taken into account when interpreting the specific type of philosophical

2 More on this in section "The literary character of the Dialogues" below. 
work such as the Dialogues, before I focus on its final part in an attempt to show that, despite how it might seem at first sight, Hume actually remains consistent in his opinions throughout the whole work. I will also briefly touch on the problem of understanding "true religion" in the Dialogues, but only insofar as it relates to the problem of identifying Hume's representative. My hope is that these considerations could make a small contribution to the shaping of a clearer picture of Hume's views on religion and his most comprehensive work concerning it. ${ }^{3}$

\section{The characters and the two other hypotheses regarding Hume's spokesperson}

The main theme of the Dialogues is answering the question of whether religious beliefs could be rationally founded (i.e. if they could be sufficiently supported by experiential evidence) by way of critically evaluating the teleological argument for God's existence. This argument is meant to show that, since the order and purpose we find in the world are like the order and purpose present in the products of human artifice, they also must be the result of the creation of an intelligent designer. Hume decides to set aside the question of whether we can prove God's existence and to consider only whether it is possible to reasonably conclude something about his nature, but by the end of the Dialogues it is clear that these two questions cannot be completely separated one from another.

Three characters are taking part in this discussion: the experimental theist Cleanthes, who thinks that religious beliefs have solid experiential support and who is the main proponent of the argument from design, the philosophical sceptic Philo, who thinks that such subjects fall outside the scope of human reason and knowledge, and the traditional orthodox theist Demea, who believes that the only way to gain knowledge of God's nature is through revelation. Cleanthes' pupil Pamphilus is also present during the conversation and the Dialogues we are reading is Pamphilus' recounting of it in a letter to his friend Hermippus, who was rather intrigued by the first

3 Although identifying Hume's spokesperson would certainly enable us to gain a better understanding of the Dialogues and possibly of Hume's final position concerning religion as well, I would like to note that I don't think it would help us reach a definitive interpretation of this work. I highly doubt that any such interpretation is actually possible. As I briefly explain in the third section of the paper, I believe that Hume wanted different people to read and take something away from this work, which would not be possible were there only one way to understand its meaning. This should not be taken as undermining the thesis that Philo is Hume's main representative, but it does mean that, even if we grant this thesis to be true or at least the most plausible one, we are still facing some difficulties when it comes to understanding what exactly Hume wanted to convey through Philo. However, I believe that every interpretation will be similarly limited, given the inherent and intentional ambiguities of the Dialogues' text, and that the one I am defending is still best supported by various evidence I shall present in the course of this paper. 
account of the discussion Pamphilus had witnessed and who had asked for a more detailed report of it. These might sound like minor details, but they will become important later on.

Throughout the Dialogues we see Philo constantly challenging and opposing Cleanthes' endeavours to establish the design hypothesis and he seems to be doing this with great success. He argues against our ability to infer from experience both God's natural and moral attributes and in response to his critiques laid out in Part $10^{4}$ Cleanthes even suggests that God is not infinitely but only finitely perfect. However, in the last section of the Dialogues, in a tête-à-tête with Cleanthes Philo suddenly confesses that, despite his "love of singular arguments, no one has a deeper sense of religion impressed on his mind, or pays more profound adoration to the divine Being, as he discovers himself to reason, in the inexplicable contrivance and artifice of nature". (DNR 12.2; KS 214) He then speaks very laudably about the argument from design and acts as if it were impossible for him to doubt it, and even produces several examples of the evidence of design in the world. $\mathrm{He}$ goes so far as to express his "veneration for true religion" (DNR 12.9; KS 219) although he doesn't say what he means by "true religion". Finally, at the very end of the Dialogues Philo explicitly accepts sceptical fideism by saying that "to be a philosophical Sceptic is, in a man of letters, the first and most essential step towards being a sound believing Christian." (DNR 12.33; KS 228) It is this part of the Dialogues and these claims that have usually been described as containing and expressing "Philo's reversal" and which have generated such controversy among the interpreters.

Of the five characters in total who are mentioned in the Dialogues, three are participants in the philosophical discussion. Nowhere in the literature have I been able to find anyone who thinks that Demea might be Hume's primary spokesperson, ${ }^{5}$ and there are good reasons for this. Demea is a rigid orthodox theist and occasionally a mystic. He thinks that God's nature is inscrutable - "altogether incomprehensible and unknown to us" (DNR 2.1; KS 141) which is why he opposes the idea of deciding anything concerning his nature on the basis of experience. When pressed to engage with the

4 Philo's main challenge in Part 10 consists in asking these questions about the being whose moral attributes Cleanthes wishes to establish: "Is he willing to prevent evil, but not able? then is he impotent. Is he able, but not willing? then is he malevolent. Is he both able and willing? whence then is evil?" (DNR 10.25; KS 198) At the beginning of Part 11 Cleanthes attempts to answer the challenge by claiming that "supposing the Author of Nature to be finitely perfect, though far exceeding mankind; a satisfactory account may then be given of natural and moral evil, and every untoward phenomenon be explained and adjusted." (DNR 11.1; KS 203)

5 The qualification "primary" is important because neither I nor the other authors writing about this question wish to say that Demea never speaks for Hume. However, when he does that, Philo and (in most cases) Cleanthes agree with him, while there is no single instance of him defending Hume's known views against the opposing views of those two characters. 
philosophical arguments he proposes "that simple and sublime argument $a$ priori" (DNR 9.1; KS 188), a version of the cosmological argument for God's existence very similar to the one that Samuel Clarke ${ }^{6}$ defended and which Hume had already criticised. ${ }^{7}$ This clearly makes Demea a bad candidate for Hume's main representative although it doesn't mean that he is not an important character in his own right. ${ }^{8}$ However, ruling him out as Hume's primary spokesperson leaves us with Philo and Cleanthes as main contenders.

Most authors today take Philo to be the obvious choice between the two or opt for the third interpretative solution which I shall mention shortly. However, before Kemp Smith's analysis of the Dialogues (in 1947) the most popular hypothesis was that Cleanthes was Hume's spokesman, and even after he offered his interpretation, according to which "Philo, from start to finish, represents Hume" (Kemp Smith 1947, 59), Harward claimed that both Philo and Cleanthes represented Hume (Harward 1975). On the other hand, and perhaps surprisingly considering that Pamphilus and Hermippus are clearly minor characters, Wieand claimed that Pamphilus should be taken as Hume's spokesperson because he is the narrator of the work who both introduces the characters and their discussion and passes the final judgement about the winner of the debate (Wieand 1985, 33-35). I believe this is the only suggestion of that kind but even the authors who wouldn't accept Pamphilus to be Hume's representative throughout the Dialogues might still think that he is speaking for Hume in the moments when he is passing those judgements. Because Pamphilus speaks very little and when he does he always agrees with Cleanthes or supports his opinions (which is only natural, considering that he is his pupil), I shall deal with the suggestions that Hume might be represented by Cleanthes and by Pamphilus together.

6 It is sometimes suggested that Hume modelled Demea on Samuel Clarke (notably in Mossner 1936, as well as in Kemp Smith's Introduction to the Dialogues), perhaps because he is the one who presents the cosmological argument in the Dialogues, but this is not very likely because Demea's mysticism doesn't align well with Clarke's rationalism and Clarke was certainly a better philosopher than Demea.

7 In the Treatise ( $\mathrm{T}$ 1.3.3) Hume discusses "a general maxim in philosophy, that whatever begins to exist, must have a cause of existence" (the maxim is a version of the famous principle of sufficient reason) and during this discussion he examines and deems question-begging Clarke's proof of the maxim. This proof and the maxim itself figure prominently in Clarke's cosmological argument in his A Demonstration of the Being and Attributes of God which is why Hume was accused of denying this argument. See fn. 1.

8 While he was virtually ignored or thought wholly insignificant before, the past few decades saw the emergence of new interest in Demea's role in the Dialogues. Thus Stove (1978), Stahl (1984), and Dye (1989) all discuss, more or less critically, Demea's arguments in Part 9. On the other hand, Vink (1986) and Dye (1992) recognize the importance of Demea's departure at the end of Part 11 for the overall direction of Part 12 of the Dialogues, while Olsewsky claims that even before his departure "Demea has a crucial and central role in the dramatic triangularity that gives impetus to the dialogue." (Olsewsky 2003, 474-75) However, none of these authors suggests that Demea might be Hume's main representative. 
The other hypothesis that I would like to consider and one that I feel has more substantial support is that no one in particular speaks for Hume in the Dialogues. This could be understood as the suggestion that more than one character speaks for Hume or that none of them speak for him but the main point is that, as Fogelin put it, "the entire dialectical structure of the Dialogues speaks for Hume." (Fogelin 2017, 101) These two alternatives are often combined to express the claim that, although all of the characters sometimes speak for Hume, none of them does so consistently but rather the Dialogues as a whole, when properly understood, reveal his genuine opinions. Thus Brick thinks that the fundamental mistake in interpreting the Dialogues, which leads to many other mistakes, consists in believing that one character speaks for Hume (Bricke 1975, 3). Foley defends the same view and claims that the characters in the Dialogues are rather inconsistent and that we can take Hume to be consistent only if we accept that none of them is representing his opinions (Foley 2006, 84). I find this interpretation rather plausible and valuable because it stresses the need to think about the Dialogues in its entirety and to also take into account the fact that it is a special kind of literary work. What I do not agree with is the claim that none of the characters consistently represents Hume's opinions. In what follows I will first draw attention to some of the literary aspects of the Dialogues that I think are necessary to take into consideration when interpreting the work and then I will proceed to show why Cleanthes or Pamphilus are not the right candidates for Hume's representatives. Finally, my main argument against the hypothesis that the whole work speaks for Hume will be that Philo is actually consistently defending his views and that we can gain a better understanding of Hume's own views if we consider the Dialogues in this light rather than if we take none of the characters to have this role.

\section{The literary character of the Dialogues}

The Dialogues is Hume's posthumously published work and we don't know much about his process of writing it. What we know for sure is that Hume worked on it on at least three different occasions over a period of twenty-five years and that he spent what he knew to be the last months of his life revising this work. We also know that many of his friends had endeavoured and finally managed to persuade him not to publish the Dialogues earlier, but that he took great care to make sure it would be published after his death. ${ }^{9}$ It

9 It turned out that this would be more difficult to achieve than Hume had expected. He first tried very hard to persuade his good friend Adam Smith to publish it but with no success. Smith wrote to William Strahan that he "could have wished [that the Dialogues] had remained in manuscript to be communicated only to a few people" (HL2, 453) and he clearly didn't want his name to be in any way connected to this work. Strahan, who was Hume's publisher, initially agreed to publish it but after Hume's death he obviously deemed it improper and refrained from complying with his wishes. Finally, Hume's 
was obviously important to Hume that his work sees the light of day and he seemed to be satisfied with the final version of it. In a letter to Adam Smith, written ten days before his death, he says that after the newest revisions he found "that nothing can be more cautiously and more artfully written." (HL2, 334, my emphasis) We could understand the word "artfully" to mean "with artistic skill", but I believe that we should actually take it to mean "skilfully" or maybe "cunningly". The fact that Hume also says that the Dialogues is "cautiously" written suggests that he was well aware of its contents being controversial. He wrote the letter to tell Smith that he shouldn't have scrupled to publish the Dialogues (which Smith had done), so we have reasons to suppose that he wanted to tell him that whatever was objectionable in the work was at least expressed very carefully.

Why did Hume feel the need to be so cautious when he knew the Dialogues were going to be published posthumously? I believe there are several reasons for this. On the one hand, he wanted to make sure that his work would actually be published, and he realised how difficult that would be if the Dialogues were thought to further atheism. On the other hand, I don't think it was Hume's intention at all to give ready answers in his Dialogues. We know that he revised and expanded Part 12 shortly before he died ${ }^{10}$ and it is precisely that part which prevents us from readily answering questions concerning his representative and his religious views in the Dialogues. The final version of the text made several interpretations at least plausible. This meant that different thinkers could gain something from engaging with his work without outright condemning it for atheism, even if it was still undoubtedly perceived as prevalently anti-religious. I also believe, but I cannot argue for that point in more detail here, that Hume didn't mean to conceal either his atheism or his deism in the Dialogues, but rather to really subtly argue for scepticism. If this were correct it would explain why it is so difficult to find any definite answers in this work.

The Dialogues is not only a philosophical work, but a work of literature at the same time. It is, as its title says, written in dialogue form, a kind of literary form which Hume didn't use very often but which he seems to have considered especially apt for writing about the subjects he writes about in

nephew David Hume Younger saw it through the press in 1779, three years after his uncle's death and according to his wish. Hume was obviously uncertain that any of his friends would have the courage to publish the Dialogues and he wrote to Strahan that if, for whatever reason, he did not publish the work within two and a half years of Hume's death then "the Property shall return to my Nephew, David, whose Duty, in publishing them as the last Request of his Uncle, must be approved of by all the World." (ibid.) For a more detailed story about the publication of the Dialogues I would like to direct readers to Chapter 10 of Rasmussen's book, as well as to the Appendix M of HL2.

10 Stewart has shown that the only paragraph added in 1776 was the longest paragraph in Part 12, where Philo argues that the dispute between theists and atheists is purely verbal (Stewart 2000, 303). I discuss this paragraph briefly in the penultimate section of the paper. 
the Dialogues. Another one of his writings that features this literary form is Section 11 of the first Enquiry, in which he also examines the argument from design. I already noted that the structure of the Dialogues is very peculiar ${ }^{11}$ - we as readers share Hermippus' position and hear about the conversation between three interlocutors from Pamphilus, who is the pupil and protégé of Cleanthes. He doesn't hesitate to express his agreement with his teacher and we may rightly wonder how reliable a narrator he is. In addition to this, Hume's Dialogues differs from the majority of other philosophical dialogues, both ancient and modern, precisely in the fact that there is not one dominant character of whom we can say with certainty that this person represents the author's views.

From the introductory part of the Dialogues, through the words of Pamphilus, we learn that Hume gave much thought to the specificities, both advantages and disadvantages, of this literary form, especially when philosophers make use of it. Pamphilus informs us that in a dialogue "the order, brevity, and precision" typical for a philosophical exposition are sacrificed to preparations, transitions and a mix of various topics thrown in to make the conversation sound more natural (DNR 0.1; KS 127). However, there are certain subjects "to which dialogue-writing is peculiarly adapted, and where it is still preferable to the direct and simple method of composition." (DNR 0.2; KS 127) Such subjects are at the same time obvious and important, but also both obscure and uncertain, and Pamphilus remarks that "these circumstances are all to be found in the subject of natural religion" (DNR 0.5; KS 128). He also explains that the dialogue-writer who wants to carry "the dispute in the natural spirit of good company" tries to preserve "a proper balance among the speakers" (DNR 0.1; KS 127), which is one of the reasons why it is so difficult to identify Hume's spokesperson, but he never says that there can be no such person.

So we are warned right from the beginning about what we should and shouldn't expect to find in Hume's Dialogues, which Vink helpfully summarizes in this way: "[w]e may expect the relations among the participants in the discussion to be of importance; a number of problems to be discussed, not all of them as thorough as perhaps should be; a certain balance among the speakers to be aimed at deliberately; some passages to function as preparations and transitions; order, brevity and precision not to be the main concern." (Vink 1986, 389) That is why it is surprising to see that Bricke, who justly claims that the right way of approaching the Dialogues is "one

11 The dialogue in the Enquiry also has a rather unusual structure - Hume is recounting to the readers the conversation he recently had with a friend "who loves sceptical paradoxes" and in this conversation they enacted Epicurus' defence before the Athenian people, where Hume represented the Athenian people while his friend, in the role of Epicurus, argued against the teleological argument. Hume also took care to mention right at the beginning that this friend of his "advanced many principles, of which I can by no means approve" (EHU 11.1; SBN 132). 
which puts proper stress on Hume's literary objectives in their composition" (Bricke 1975, 3) also thinks "that neither Philo nor Cleanthes [...] could be Hume's spokesman, for each is often unHumean in his views, and neither maintains a reasonably clear, well-argued, self-consistent position in the course of the Dialogues" (ibid.). I will address the claim that both characters are unHumean below, but I would like to point out here that, if we really pay attention to Hume's literary objectives, then the fact that his characters aren't always well-argued or wholly consistent shouldn't come as a surprise. Hume already informed us that he didn't create his dialogue or his characters to be that way and Bricke's contention is not a valid objection to any of them being Hume's spokesperson.

Finally, it is well-known that Hume uses irony in the Dialogues, especially through the character of Philo. This further complicates the interpretation of this work because the irony is sometimes very obvious (as when Philo represents himself as Demea's ally) but at other times we could be missing it and, in consequence, wrongly interpreting certain parts of the discussion. On the other side, there is the opposite danger of thinking that Hume is being ironic when he actually isn't or of trying to explain away any difficult passages by ascribing them to Hume's or Philo's irony. Because of all of this we should be very careful when we are attributing certain statements to either one of the characters or to the author and it is important to remember at all times the aforementioned factors we ought to take into account when interpreting the Dialogues.

\section{Against the view that Cleanthes speaks for Hume}

At the beginning of the Dialogues we are also told about the "remarkable contrast" in the characters of the three interlocutors and we learn that, upon Pamphilus' first ("imperfect") account of the conversation he had witnessed, Hermippus "opposed the accurate philosophical turn of Cleanthes to the careless scepticism of Philo" and "compared either of their dispositions with the rigid inflexible orthodoxy of Demea" (DNR 0.6; KS 129), while at the very end of the Dialogues, after seriously considering the whole discussion, Pamphilus pronounces "that Philo's principles are more probable than Demea's; but that those of Cleanthes approach still nearer to the truth." (DNR 12.34; KS 228) Here we seem to have some direct evidence for the interpretation that Cleanthes represents Hume. In addition to this, in a letter to his friend Gilbert Elliot Hume writes: "You would perceive by the Sample I have given you, that I make Cleanthes the Hero of the Dialogue. Whatever you can think of, to strengthen that Side of the Argument, will be most acceptable to me." (HL1, 153-154) Taken at face value, this would seem to confirm Pamphilus' verdict. However, apart from our having reasons to suspect Pamphilus' impartiality, what Hume says in the letter seems strange. We might ask why would he need his friend's help in strengthening Cleanthes' argument if he himself was a genuine proponent of that argument. Besides that, he didn't 
really say that Cleanthes was the hero of the Dialogues, but only that he made him so. He continues the letter: "Any Propensity you imagine I have to the other Side, crept in upon me against my Will: And tis not long ago that I burned an old Manuscript Book, wrote before I was twenty; which contained, Page after Page, the gradual Progress of my Thoughts on that head." (HL1, 154) Despite the proclamation that it crept in upon him against his will, this implies that Hume himself felt he had more affinity for Philo's than for Cleanthes' views. If this was the case it would make sense that he needed help in strengthening Cleanthes' argument, whatever his reasons for wishing it might have been. Finally, "the old manuscript book" Hume mentioned in the letter is probably something he wrote while he was writing the Treatise, and maybe even something he had intended to include in the Treatise but later refrained from it. ${ }^{12}$ In any case, it must have contained sceptical thoughts on religion, since Hume here claims that it was in line with Philo's side of the argument.

Although Hume's Dialogues differ from the majority of other well-known philosophical dialogues, we find one important exception. There is actually a striking similarity between Hume's Dialogues and Cicero's De natura deorum which should not be overlooked because it potentially provides us with very helpful insights into Hume's structuring the Dialogues precisely the way he did. ${ }^{13}$ In Cicero's dialogue there are also three main participants: Velleius the Epicurean, Balbus - the Stoic, and Cotta - the Academic Sceptic. Cicero himself is present mainly as a narrator and listener, in a similar way in which Pamphilus is present in Hume's dialogue, but historical Cicero obviously endorsed the views advanced by Cotta, who clearly wins the debate. However, De Natura Deorum ends with Cicero saying: "Cotta's argument seemed to Velleius to be more truthful, but in my eyes Balbus' case seemed to come more closely to a semblance of the truth." (Cicero 1997, 146) We know that Hume greatly admired Cicero and his style of writing so it is not surprising that he took inspiration from Cicero's dialogue's ending. ${ }^{14}$ If we have this in

12 We already know that Hume wrote the first draft of his essay "On miracles" (Section 10 of the first Enquiry) well before he published the Treatise, because he wrote to Henry Home in 1937: "[I] enclose some Reasonings concerning Miracles, which I once thought of publishing with the rest, but which I am afraid will give too much offence" (HL1, 24) and in the same letter he informed Home that he was at the time castrating his work, "that is, cutting off its nobler parts, that is, endeavouring it shall give as little offence as possible" before he could show it to Bishop Butler (HL1, 25). It is possible that Hume wrote another piece on religion at this time which he decided not to publish with the rest.

13 Cicero's influence on the Dialogues has been widely recognised, particularly in Price 1964, Battersby 1979, and Fosl 1994.

14 Hume took inspiration from Cicero for more than just the ending of the Dialogues. In Cicero's dialogue Velleius says that Philo (talking about Philo of Larissa, an Academic Sceptic) was both Cicero's and Cotta's teacher: "both of you have been taught by the same teacher Philo to know nothing." (Cicero 1997, 9) Balbus, on the other hand, mentions that Cleanthes belongs to their (Stoic) school (Cicero 1997, 52) - meaning Cleanthes of 
mind and the fact that Cleanthes clearly wasn't the winner of the debate in the Dialogues, then the fact that Pamphilus considers him to be the winner and that Hume names him the hero of the Dialogues doesn't provide us with good reasons to think that Cleanthes represents Hume's views.

In the previously cited letter to Elliot Hume also writes the following:

"I have often thought that the best way of composing a dialogue would be for two persons that are of different opinions about any question of importance, to write alternately the different parts of the discourse, \& reply to each other. By this means, that vulgar error would be avoided, of putting nothing but nonsense into the mouth of the adversary: And at the same time, a variety of character \& genius being upheld, would make the whole look more natural \& unaffected. Had it been my good fortune to live near you, I should have taken on me the character of Philo in the dialogue, which you'll own I could have supported naturally enough: And you would not have been averse to that of Cleanthes." (HL1, 154, my emphasis)

Here we can see again how much Hume wanted his dialogue to give the impression of being natural and his characters to feel genuine. He obviously disliked dialogues of a Socratic kind and he made a conscious effort not to have one character dominate the conversation the whole time. However, the fact that he said that he would have left the role of Cleanthes to Elliot, while he himself could have supported Philo "naturally enough" also implies that the intended hero of the Dialogues is not the one with the views closest to his own. Therefore, neither Pamphilus' verdict at the end of the Dialogues nor Hume's letter to Elliot provide good evidence for the hypothesis that Cleanthes represents Hume in the Dialogues.

\section{Philo's scepticism}

What about Hermippus' opposition ${ }^{15}$ of "the accurate philosophical turn of Cleanthes to the careless scepticism of Philo" (DNR 0.6; KS 129)?

Assos, a Greek Stoic philosopher and successor to Zeno of Citium as the second head of the Stoic school in Athens.

15 My referring to Hermippus' comparing and contrasting the characters here might seem strange because he himself is barely a character in the Dialogues and he never utters a word throughout the book. However, Pamphilus explicitly says in the Introduction that Hermippus' expectations were raised by "the remarkable contrast" in the interlocutors' characters and that Hermippus opposed different philosophical approaches of Cleanthes, Philo and Demea. He also informs us that Hermippus shared these opinions with him after having read Pamphilus' first and imperfect account of the conversation between the three main characters. This exchange of letters took place before Pamphilus' narrating the Dialogues to Hermippus and to us, and everything we know of Hermippus' opinions comes from Pamphilus who never informs us whether Hermippus' views were changed after the second, presumably less imperfect, account. Without delving into the question of why Hume introduced the character of Hermippus at all while at the same time 
Philo's scepticism is sometimes characterised as excessive. At the beginning of the Dialogues Cleanthes accuses him of advocating Pyrrhonism, but Philo explains that his scepticism is of the kind that Hume openly accepts and calls moderate or mitigated scepticism. He doesn't use that term but he describes his scepticism in much the same way and using almost the same words that Hume uses in the first Enquiry. When Cleanthes first challenges the tenability of Philo's sceptical position he is being rather ironical: "Whether your scepticism be as absolute and sincere as you pretend, we shall learn by and by, when the company breaks up: We shall then see, whether you go out at the door or the window; and whether you really doubt, if your body has gravity, or can be injured by its fall [...]" (DNR 1.5; KS 132). He then proceeds in a more serious tone to show that human beings are incapable of enduring total scepticism. His main point is that, even though a man may momentarily, after intensely reflecting on the imperfections of our faculties and the groundlessness of our beliefs, "entirely renounce all belief and opinion, it is impossible for him to persevere in this total scepticism, or make it appear in his conduct for a few hours." (ibid.) He may be able to follow these sceptical principles while he is engaging with philosophical arguments, but as soon as he turns to the more mundane things "the bent of his mind relaxes" and "the philosopher sinks by degrees into the plebeian." (DNR 1.7; KS 133) According to him sceptical philosophy simply cannot have any lasting influence.

While this critique of excessive scepticism is entirely Humean, and mirrors Hume's earlier critiques of what he calls Pyrrhonism in the Treatise and in the first Enquiry, Philo's answer is not less Humean. He agrees with Cleanthes that, as much as someone may be sceptical in philosophy, "he must act, I own, and live, and converse like other men; and for this conduct he is not obliged to give any other reason, than the absolute necessity he lies under of so doing." (DNR 1.9; KS 134) In other words, although philosophy teaches us that we are by no means able to justify even our most fundamental beliefs and that our faculties are constantly leading us to erroneous conclusions, we continue to have those beliefs and use those faculties because we cannot help it - "[n]ature, by an absolute and uncontrollable necessity has determined us to judge as well as to breathe and feel" (T 1.4.1.7; SBN 183), as Hume himself says in the Treatise. However, this doesn't mean that scepticism cannot have any lasting influence. Contrary to that, Philo claims that a man who "has accustomed himself to sceptical considerations" won't entirely forget them, but he will, both in his philosophy and in his everyday conduct, differ from those who have never experienced such sceptical doubts. (DNR 1.9; KS 134) How will he differ from them? He will continue to philosophise because he finds pleasure in it, ${ }^{16}$ however, he will confine his enquiries to the subjects

distancing the readers from him as much as possible, I will refer to Hermippus' opinions wherever Pamphilus refers to them in such way.

16 This is exactly what Hume cites as his reason to continue doing philosophy after serious sceptical crisis at the end of the Book I of the Treatise. He describes the curiosity about 
that are within the bounds of our experience and concerning which we can "make continual advances in forming more general principles of conduct and reasoning", but he won't carry his speculations much farther (DNR 1.9- 1.10; KS 134-135). This is quite similar to Hume's position at the end of the first Enquiry, where he claims that mitigated scepticism or academical philosophy, "which may be both durable and useful," is in part "the result of this Pyrrhonism, or excessive scepticism, when its undistinguished doubts are, in some measure, corrected by common sense and reflection." (EHU 12.24; SBN 161) He also explicitly says that one aspect of this philosophy, which is the natural result of Pyrrhonism, is "the limitation of our enquiries to such subjects as are best adapted to the narrow capacity of human understanding." (EHU 12.25; SBN 162) He ends these considerations with the following words:

"Those who have a propensity to philosophy, will still continue their researches [...] But they will never be tempted to go beyond common life, so long as they consider the imperfection of those faculties which they employ, their narrow reach, and their inaccurate operations. While we cannot give a satisfactory reason, why we believe, after a thousand experiments, that a stone will fall, or fire burn; can we ever satisfy ourselves concerning any determination, which we may form, with regard to the origin of worlds, and the situation of nature, from, and to eternity?" (EHU 12.25; SBN 162)

And in the Dialogues Philo says:

"Let us become thoroughly sensible of the weakness, blindness, and narrow limits of human reason: Let us duly consider its uncertainty and endless contrarieties, even in subjects of common life and practice [...] When the coherence of the parts of a stone, or even that composition of parts, which renders it extended; when these familiar objects, I say, are so inexplicable, and contain circumstances so repugnant and contradictory; with what assurance can we decide concerning the origin of worlds, or trace their history from eternity to eternity?" (DNR 1.3; KS 132)

I believe that this strongly suggests that Hume and Philo at least share the same sceptical outlook. To return now to Hermippus' characterisation, we don't have to understand "careless" to mean "reckless". We could understand it to mean "care-free", as Lorkowski suggests (Lorkowski 2016, 260), since this seems to be the meaning in which Hume used this word in the concluding section of the Treatise when he wrote that " $\mathrm{t}]$ he conduct of a man, who studies philosophy in this careless manner, is more truly sceptical than that of one,

philosophical questions and the ambition to contribute to the instruction of men naturally arising in him and declares: "should I endeavour to banish them, by attaching myself to any other business or diversion, I feel I should be a loser in point of pleasure; and this is the origin of my philosophy." (T 1.4.7.12, SBN 271). 
who feeling in himself an inclination to it, is yet so overwhelmed with doubts and scruples, as totally to reject it." (T 1.4.7.14; SBN 273) On the other hand, when Hermippus observed that Cleanthes' philosophical turn was accurate, he didn't necessarily intend to say that his opinions or conclusions were such as well. Hume would certainly characterise Cleanthes' use of experimental method in philosophy of religion as accurate, but I don't think that he would agree with many of his philosophical claims.

\section{Against the view that the whole structure of the Dialogues speaks for Hume}

Thus far I have only discussed the hypothesis that Cleanthes or Pamphilus represent Hume in the Dialogues, but I've hardly said anything about the hypothesis that, while all characters speak for Hume, neither one of them does that consistently. However, if I manage to show that Cleanthes doesn't defend Hume's opinions at some important moments and that Philo does that at all times, I will have sufficiently argued against both hypotheses. In other words, if I manage to show that Philo consistently defends Hume's views, then I have ipso facto shown that Cleanthes doesn't and that it is not true that none of the characters is Hume's primary spokesman. Before I proceed to attempt to do this, I would like to clarify a few things with regard to this hypothesis.

The claim that the Dialogues as a whole speak for Hume is trivially correct because he is the author of this work and it reflects in its entirety his process of thinking about natural theology. Saying that "the entire dialectical structure" of the book speaks for Hume is even more accurate because it underlines his struggles in looking for answers to some of the questions he discussed. In spite of that, I don't see good reasons to favour this hypothesis over the one that Philo primarily speaks for Hume. It is important to understand that, in claiming that Philo represents Hume in the Dialogues, I am not claiming that other characters never express any of his opinions. We have already seen that we might plausibly suppose that Pamphilus speaks for Hume when he discusses the peculiarities of the philosophical dialogues at the beginning of the book. There is also an overall consensus among the interpreters that Cleanthes speaks for Hume when he is attacking the ontological and the cosmological arguments in Part 9 of the Dialogues, but it is at the same time clear (and Hume makes sure that Cleanthes mentions this in D 9.4; KS 189) that Philo agrees with him. However, "[t]he interpretive challenge is to deduce Hume's final position in the less obvious cases, i.e. in the points over which characters intelligently disagree." (Lorkowski 2016, 256) Although both Cleanthes and - to a lesser extent - Demea make references to Humean ideas and sometimes even use Hume's well-known phrases to do so, in such cases Philo always agrees with them. On the other hand, I believe that it can be shown that Philo is the one who advances Hume's views when the others 
attack them, that he speaks for him most often and most consistently and that his views on religion agree with Hume's views on it that we are familiar with from his other works, from which Cleanthes' and Demea's views clearly differ. That is why I claim that he is not Hume's only but, rather, his primary representative.

There is also one subsidiary textual evidence against the hypothesis that none of the characters consistently speaks for Hume, which Lorkowski was the first, as far as I know, to take notice of (Lorkowski 2016, 264). In a letter from 1753 , written to one of his anonymous reviewers, Hume makes the following complaint: "But you impute to me both the sentiments of the Sceptic and the sentiments of his antagonist, which I can never admit of. In every Dialogue, no more than one person can be supposed to represent the author." (HL1, 173, my emphasis) The dialogue in question is the one appended to his Enquiry concerning the Principles of Morals but it is clear from his wording that what Hume says here is meant to apply to every philosophical dialogue. Furthermore, we know that he had already written a considerable portion of the Dialogues, if not the whole work, by this time, since this letter is dated two years after the aforementioned letter he wrote to Elliot. Therefore, this evidence supports the hypothesis that Hume also thought that only one character should be supposed to represent the author in his Dialogues. In what follows I hope to show this to be true even regardless of this evidence by showing that no one but Philo consistently speaks for him throughout the Dialogues.

\section{"Philo's reversal" in DNR 12}

If everything that I endeavoured to establish thus far is accepted, then the biggest obstacle to identifying Hume with Philo is Philo's alleged change of opinion in Part 12 of the Dialogues. This part opens with Philo suddenly confessing to Cleanthes, after Demea had left the company, that despite his "love of singular arguments, no one has a deeper sense of religion impressed on his mind, or pays more profound adoration to the divine Being, as he discovers himself to reason, in the inexplicable contrivance and artifice of nature". (DNR 12.2; KS 214) Furthermore, he claims that "a purpose, an intention, a design strikes everywhere the most careless, the most stupid thinker" (ibid.) and that "all the sciences almost lead us insensibly to acknowledge a first intelligent Author." (DNR 12.2; KS 215) In support of this he cites Galen's discoveries concerning the structure of the human body. If a man has above six hundred different muscles, then "whoever duly considers these, will find, that in each of them Nature must have adjusted at least ten different circumstances" so that in the muscles alone "above 6000 several views and intentions must have been formed and executed." (ibid.) If we also include in these calculations bones, skin, ligaments, vessels, glandules, and other parts of the body, then, Philo poses a rhetorical question, "how must 
our astonishment rise upon us, in proportion to the number and intricacy of the parts so artificially adjusted?" and "to what pitch of pertinacious obstinacy must a philosopher in this age have attained, who can now doubt of a Supreme Intelligence?" (ibid.)

Something here already seems a little strange and makes us wonder whether Philo is being ironical or whether he really believes that all these instances of "artificially adjusted" body parts are proofs of intelligent design. If the latter is the case, then why did he not mention it before and why did he try so hard to show that Cleanthes' examples of instances of design in the world are incapable of establishing the desired conclusion? However, what he says next makes us doubt his honesty even more. Supposing there were an imperceptible God, he asks, "were it possible for him to give stronger proofs of his existence, than what appear on the whole face of Nature?" and he appears to maintain that such a God could do no better "but copy the present economy of things; render many of his artifices so plain, that no stupidity could mistake them; afford glimpses of still greater artifices [...] and conceal altogether a great many from such imperfect creatures?" (DNR 12.4; KS 215216) He indeed seems to be endorsing the argument from design and he even adds that, "as the works of Nature have a much greater analogy to the effects of our art and contrivance, than to those of our benevolence and justice", this gives us reasons to conclude that God's natural attributes resemble man's more that his moral attributes, which can only mean that man's moral attributes are more defective since God must be "absolutely and entirely perfect." (DNR 12.8; KS 219) If we've ever read the previous eleven parts of the Dialogues we must be extremely confused at this point because there Philo argued over and over again that the argument from design cannot succeed in establishing either God's natural or his moral attributes, and besides this, I have already mentioned that he made Cleanthes accept in Part 11 that God could only be finitely perfect. Why is he now contradicting himself? He doesn't give any reasons for suddenly reversing his earlier opinions. He doesn't even acknowledge that there has been such a reversal of his views and he certainly never refutes any of his previous arguments.

This has led some authors to suggest that there might be some irrational basis for theism in our nature that we simply cannot avoid. I shall only briefly comment on one such view, similarly expressed by Lorkowski (Lorkowski 2014; 2016) and Fogelin (Fogelin 2017), according to which in Part 12 of the Dialogues Philo doesn't endorse the argument he had been refuting thus far, but he actually assents to what is called the irregular teleological argument. In Part 3 of the Dialogues Hume draws a difference between the regular and the irregular teleological argument, where by the "regular argument" he means the argument from design that is based on analogical or abductive reasoning, and by the "irregular argument" he means Cleanthes' assertion that the consideration of purposefulness in nature (the curious adaptation of means to ends) makes the idea of a contriver "immediately flow in upon you 
with a force like that of sensation." (DNR 3.7; 154) Cleanthes in Part 3 claims that even a sceptic must "adhere to common sense and the plain instincts of nature; and to assent, where-ever any reasons strike him with so full a force, that he cannot, without the greatest violence, prevent it." (ibid.) Philo didn't respond to this argument and Pamphilus noticed that he was a little embarrassed and confused upon hearing it (DNR 3.10; KS 155). Lorkowski and Fogelin believe that he remained silent because he couldn't find a way to oppose this argument and that Hume here wanted to say that religious beliefs are natural in a way. Fogelin describes this sort of belief as "immediate and, when it occurs, irresistible." (Fogelin 2017, 96) Lorkowski admits that religious beliefs are not natural in the same way beliefs in causation are, because they are neither universal nor necessary for our survival, but he thinks they are still natural in some weaker sense because they are the consequence of "our universal, instinctual propensity to believe that the order of the universe is intended. It is not an inference but is akin to sensation, making the belief non-inferential and therefore natural." (Lorkowski 2016, 255)

Without entering into discussion concerning the nature of religious belief, ${ }^{17}$ I would like to observe that this suggestion, even if we grant that religious beliefs could be in some way natural, doesn't seem to be a very plausible explanation of "Philo's reversal". Firstly, if this was really Hume's main conclusion concerning religious beliefs, then he did a very lousy job of presenting it to the readers. If Philo was indeed convinced by Cleanthes' irregular argument in Part 3, then the discussion should have ended then and there or, if it was continuing only in order to show that the belief in an intelligent author cannot be rationally justified, although it was established that it was natural and irresistible, this could and probably would have been made sufficiently clear. Secondly, and more importantly, there is no evidence in Part 12 that an "instinctual propensity to believe that the order of the universe is intended" was what caused Philo to express his "adoration" of the divine being. Furthermore, he explicitly claims that this divine being "discovers himself to reason" which implies that his belief in God is not the result of something "akin to sensation". He simply doesn't seem to be assenting to the irregular argument, notwithstanding his claim that a purpose and an intention strikes everywhere "even the most stupid thinker", which sounds more ironical than anything else, since he certainly didn't consider himself stupid. He also explicitly claims that his conclusions concerning God's natural and moral attributes are the result of an analogical design argument. Moreover, when he mentions the atheists, who certainly wouldn't consent to having any such universal propensity to believe in God, he claims that their atheism is only nominal because even they would admit there to be "a certain degree of analogy among all the operations of Nature." (DNR 12.8; KS 218) Again, he is mentioning the analogical argument for design, but we don't see

17 Very interesting ideas on these topics could be found in Gaskin 1988, Part One, Ch. 7; McCormick 1993; Lorkowski 2014. 
him returning to the irregular argument from Part 3, which is why we have to look for a different explanation of his alleged reversal.

After Philo's initial confession a large portion of Part 12 of the Dialogues is dedicated to discussing the question of practical consequences of religion. Along with his "veneration for true religion" Philo also expresses his "abhorrence of vulgar superstitions", to which Cleanthes retorts that "religion, however corrupted, is still better than no religion at all." (DNR 12.9-12.10; KS 219-20) Philo strongly disagrees with this and claims that religion "as it has commonly been found in the world" has a rather bad influence on human society and its morality, often bringing about creation of various fractions, persecutions, civil wars, oppression and generally nurturing religious fanatics who act immorally in order to achieve some higher religiously inspired end (DNR 12.11; KS 220). Upon hearing this and realising that Philo's stance towards religion is still highly critical, Cleanthes warns him: "take care: push not matters too far: allow not your zeal against false religion to undermine your veneration for the true." (DNR 12.24; KS 224) However, it soon becomes clear that Philo and Cleanthes don't have the same idea in mind when they speak of "true religion", for Cleanthes then expresses the following conviction:

"The most agreeable reflection, which it is possible for human imagination to suggest, is that of genuine Theism, which represents us as the workmanship of a Being perfectly good, wise, and powerful; who created us for happiness, and who, having implanted in us immeasurable desires of good, will prolong our existence to all eternity, and will transfer us into an infinite variety of scenes, in order to satisfy those desires, and render our felicity complete and durable." (ibid.)

To the careful reader of the Dialogues this should sound almost as surprising as "Philo's reversal" because "[ $t$ ]he contrast of Cleanthes' expression of adherence to some form of 'genuine theism' with his earlier accounts of the argument from design is remarkable." (Lemmens 2012a: 290) Lemmens thinks that, although his defence of this argument seems at first to be separated from traditional Christianity, Cleanthes in Part 12 "links his experimental theology explicitly with the apologetic purposes he had in mind the whole time." (Lemmens 2012a, 285) I am not sure whether this is the best way to explain Cleanthes' reversal because to me it seems that he actually dismisses experimental theology rather than linking it to his Christian beliefs. In this part of the Dialogues he even claims that " $[\mathrm{t}]$ he doctrine of a future state is so strong and necessary a security to morals, that we never ought to abandon or neglect it" (DNR 12.10; KS 220) and so it becomes evident that his God is the traditional Christian God who cares about our well-being. Cleanthes now describes him as "perfectly good, wise, and powerful" although he previously conceded that God could only be finitely perfect. Because this form of theism cannot be derived from the argument from design, for nothing in our experience of the world warrants the beliefs in personal providential deity 
of traditional Christianity, I believe that Lemmens is right to conclude that "there is a conceptual gap lurking between the argument from design [...] and the genuine providential theism unfolded in the last part." (Lemmens 2012a, 291) This discovery makes the fact that Cleanthes was unusually unperturbed by Philo's rather successful attacks on his argument from design less surprising, because it now becomes clear that his faith never rested on any experiential grounds.

Philo, on the other hand, rejects the idea that eternal reward and punishment are the source of human morality. Instead he says that "the smallest grain of natural honesty and benevolence has more effect on men's conduct, than the most pompous views, suggested by theological theories and systems" (DNR 12.13; KS 221), thus pointing towards Hume's wellknown moral theory according to which the source of human morality lies in human nature and the sentiments of approval and disapproval rather than religion. He agrees with Cleanthes' claim that religion offers us consolation, but he explains this to be the case because "terror is the primary principle of religion" and he further claims that "both fear and hope enter into religion" (DNR 12.29; KS 225-226), which is exactly what Hume says in The Natural History of Religion concerning the origin of religion in human nature (NHR 2.4). When we look closer, Part 12 of the Dialogues abounds with evidence that Philo is actually defending Hume's views on religion, while Cleanthes' reversal ${ }^{18}$ shows that the same could not be said of him. I now turn to the conclusion of this part in order to provide the last piece of evidence for the claim that Philo remains consistent throughout the whole Dialogues.

\section{Philo's final speech in the Dialogues}

In his last speech in the Dialogues Philo says:

"If the whole of Natural Theology, as some people seem to maintain, resolves itself into one simple, though somewhat ambiguous, at least undefined proposition, That the cause or causes of order in the universe probably bear some remote analogy to human intelligence: If this proposition be not capable of extension, variation, or more particular explication: If it affords no inference that affects human life, or can be the source of any action or forbearance: And if the analogy, imperfect as it is, can be carried no farther than to the human intelligence; and cannot be transferred, with any appearance of probability, to the other qualities of the mind: If this really be the case, what can the

18 Surprisingly, Cleanthes' reversal was almost entirely overlooked in the secondary literature on the Dialogues until Lemmens drew attention to it (in Lemmens 2012a, 2012b). 
most inquisitive, contemplative, and religious man do more than give a plain, philosophical assent to the proposition, as often as it occurs; and believe that the arguments, on which it is established, exceed the objections, which lie against it?" (DNR 12.33; KS 227)

It looks like the most Philo is willing to accept is only a minimal conclusion of the design argument - the claim that there is probably some remote analogy between the cause or causes of order in the universe and human intelligence. The words "probably" and "remote" suggest that he accepts a very limited claim, which he also characterises as "ambiguous" and "undefined" and he limits it further by saying that he accepts it only insofar as it doesn't affect human life. Philo's God is obviously not the personal God of Christianity, he only stands for a vague idea of some cause or causes of the world which is/ are in some ways similar to human mind and completely indifferent when it comes to human morality and our practical lives.

Moreover, we shouldn't attach much importance to the fact that Philo accepts that there is some analogy or similarity between this "cause or causes" and human intelligence. He already said before that there is "a certain degree of analogy among all the operations of Nature" so that "the rotting of a turnip, the generation of an animal, and the structure of human thought" may be some "energies that probably bear some remote analogy to each other." (DNR 12.8; KS 218) He here repeats the words "probably" and "remote" and his irony couldn't be more obvious. ${ }^{19}$ He likewise suggests that the whole dispute concerning theism should be understood as merely verbal. The theist would certainly agree that the analogy between human and divine intelligence is very remote, since God's intelligence must be infinitely superior to human, while the atheist would consent to there being some kind of analogy between human and divine mind, because there is a certain degree of analogy among everything that exists. Their disagreement, therefore, concerns only the "degrees of quality" that cannot be exactly measured, which is why this dispute can never reach a final conclusion. (DNR 12.7; KS 217-219) I think that Penelhum is right in saying that "the message throughout these paragraphs is that the analogies on which the Design argument hinges are too vague to be worth denying, and therefore are too inconsequential to constitute significant assertions." (Penelhum 2012, 208) The consequences of this explanation with regard to Philo's "true religion" are clear. If there is some remote analogy between everything in nature, then the claim that there is this unspecified analogy between human and divine mind doesn't say anything meaningful, and if "true religion"

19 If we accept the interpretation of Philo's reversal and Philo's final conclusion in DNR 12 which I have offered in this paper, then we also ought to interpret Philo's recommendation of sceptical fideism at the end of the Dialogues as deeply ironical, because he obviously doesn't consider classical Christianity to be a very desirable or recommendable religious standpoint. 
comes down to the acceptance of one such conclusion, then this religion "is not a very religious religion." (Penelhum 2012, 209)

\section{Conclusion}

Finally, I would like to briefly touch on the question that is not the subject of my paper but that is very closely connected to it. If the meaning of Philo's true religion is really what I attempted to establish above, and if he represents Hume in the Dialogues, how should we best characterise Hume's views on religion? Many among Hume's contemporaries considered him to be an atheist, and many interpreters today consider him to be an undercover or closeted atheist because he doesn't openly admit his atheism (Cordry 2011, Penelhum 2008, 2012, Lemmens 2012). However, a careful reading of his writings shows that he doesn't accept it even implicitly. He attacks different arguments for theism but he almost never tries to prove that their conclusions are wrong. He mainly insists on our having insufficient evidence to claim that they are true. On the other hand, and mostly because of Philo's final speech Hume was characterised as a deist, and Gaskin famously described his deism as attenuated (Gaskin 1988). While he did in the end accept that the cause or causes of order in the universe bear some remote analogy to human mind, this conclusion is so ambiguous and weak that I don't think it gives us good reasons to call him a deist. The way he characterised them, there might be a plurality of such causes and they might not be any kind of deity after all. We could describe Hume's position as irreligion (Russell 2016), because Philo deprives religion of any truly religious content, but I think it would be best to describe it in the same way he himself describes his position in other places - as scepticism. Hume believes that our enquiries often take us too far, especially when we concern ourselves with religion, and then we simply don't know what to say:

"When we carry our speculations into the two eternities, before and after the present state of things; into the creation and formation of the universe; the existence and properties of spirits; the powers and operations of one universal spirit, existing without beginning and without end; omnipotent, omniscient, immutable, infinite, and incomprehensible: We must be far removed from the smallest tendency to scepticism not to be apprehensive, that we have here got quite beyond the reach of our faculties." (DNR 1.10; KS 134)

In claiming that one very ambiguous proposition is the whole content of true religion, Hume is telling us that there seems to be nothing more determinate we could say about that subject. 


\section{References to Hume's works}

T Hume, David. 2009. A Treatise of Human Nature. Edited by David Fate Norton and Mary J. Norton. Oxford: Oxford University Press. Refrences are to to book, part, section, and paragraph, followed by page references to the Selby-Bigge/Nidditch edition.

Hume, David. 1978. A Treatise of Human Nature. Edited by L. A. Selby-Bigge, rev. by P. H. Nidditch. Oxford: Clarendon Press.

EHU Hume, David. 1975. Enquiries Concerning Human Understanding and Concerning the Principles of Morals. Edited by L. A. Selby-Bigge, rev. by P. H. Nidditch. Oxford: Clarendon Press.

Hume, David. 2000. An Enquiry concerning Human Understanding. Edited by Tom L. Beauchamp. Oxford: Clarendon Press. References are to section and paragraph, followed by page references to the Selby-Bigge/Nidditch edition.

DNR Hume, David. 1948. Dialogues concerning Natural Religion. Edited by Norman Kemp Smith. 2nd ed. New York: Social Science Publishers. References are to part and paragraph, followed by page references.

NHR Hume, David. 2007. The Natural History of Religion. In A Dissertation on the Passions and the Natural History of Religion. Edited by Tom L. Beauchamp. Oxford: Oxford University Press. References are to section and paragraph.

LG Hume, David. 2007. A Letter from a Gentleman to his Friend in Edinburgh. In (prir.) An Enquiry Concerning Human Understanding and Other Writings, Edited by Stephen Buckle, 147-162. Cambridge: Cambridge University Press. References are to page number.

LH Greig, J. Y. T. 1932. The Letters of David Hume, 2 Vols. Oxford: Clarendon Press. References are to volume and page number.

\section{References to other works}

Battersby, Christine. 1979. "The Dialogues as original imitation: Cicero and the nature of Hume's scepticism." In McGill Hume Studies, edited by David F. Norton, Nicholas Capaldi and Wade L. Robison, 239 -52. San Diego: Austin Hill Press.

Bricke, John. 1975. "On the Interpretation of Hume's Dialogues." Religious Studies 11 (1): 1-18.

Cicero, Marcus Tullius. 45 BCE/1997. The Nature of the Gods. Translated by PG. Walsh. Oxford: Oxford University Press. 
Cordry, Benjamin S. 2011. "A more dangerous enemy? Philo's 'confession' and Hume's soft atheism." International Journal for Philosophy of Religion 70: 61-83.

Dye, James. 1989. “A Word on Behalf of Demea." Hume Studies 15: 120-40.

Dye, James. 1992. "Demea’s Departure." Hume Studies 18: 467-81.

Fogelin, Robert J. 1983. “The Tendency of Hume's Skepticism.” In The Skeptical Tradition, edited by Myles Burnyeat, 397-412. Berkley: University of California Press.

Fogelin, Robert. 2017. Hume's presence in the Dialogues concerning natural religion. New York: Oxford University Press.

Foley, Rich. 2006. "Unnatural Religion: Indoctrination and Philo's Reversal in Hume's Dialogues Concerning Natural Religion." Hume Studies 32 (1): 83-112.

Fosl, Peter S. 1994. "Doubt and Divinity: Cicero's Influence on Hume's Religious Skepticism." Hume Studies 20 (1): 103-120.

Gaskin, J. C. A. 1988. Hume's Philosophy of Religion. Second Edition, London: Palgrave-MacMillan.

Harward, D. W. 1975. “Hume's Dialogues Revisited." International Journal for Philosophy of Religion 6: 137-153.

Kemp Smith, "Introduction", In Dialogues concerning Natural Religion. Edited by Norman Kemp Smith, 1-75. 2nd ed. New York: Social Science Publishers.

Lemmens, Willem. 2012a. "Hume's Atheistic Agenda: Philo's Confession in Dialogues 12." Bijdragen, International Journal in Philosophy and Theology 73 (3): 281-303.

Lemmens, Willem. 2012b. "The 'true religion' of the sceptic: Penelhum reading Hume's Dialogues." Canadian Journal of Philosophy 42 (S1): 183-197.

Lorkowski, Chris M. 2014. "Attenuated Deism and Hume's Propensity to Believe." Society and Politics 8 (1): 60-77.

Lorkowski, Chris M. 2016. "Doxastic Naturalism and Hume's Voice in the Dialogues." The Journal of Scottish Philosophy 14 (3): 253-274.

McCormick, Miriam. 1993. "Hume on Natural Belief and Original Principles." Hume Studies 29 (1): 103-116.

Mossner, Ernest C. 1936. “The Enigma of Hume.” Mind, NS 45 (179): 334-349.

Olshewsky. Thomas M. 2003. "Demea's Dilemmas." British Journal for the History of Philosophy 11(3): 473-492. 
Penelhum, Terence. 2012. "Hume's atheism and the role of Cleanthes." Canadian Journal of Philosophy 42 (S1): 206-211.

Price, John Valdimir. 1964. "Sceptics in Cicero and Hume." Journal of the History of Ideas, Vol. 25, No. 1: 97-106.

Rasmussen, Dennis C. 2017 The Infidel and the Professor: David Hume, Adam Smith and the Friendship that Shaped Modern Thought. New Jersey: Princeton University Press.

Russell, Paul. 2016. "Hume's Philosophy of Irreligion and the Myth of British Empiricism." In The Oxford Handbook of David Hume, edited by Paul Russell, 109-137. New York: Oxford University Press.

Stahl, Donald. 1984. "Hume's Dialogue IX defended." Philosophical Quarterly 34: 505-507.

Stewart, M. A. 2000. “The Dating of Hume's Principal Manuscripts.” In The Scottish Enlightenment: Essays in Reinterpretation, Edited by Paul Wood, 267-314. Rochester NY: University of Rochester Press.

Stove, D. C. 1978. "Part IX of Hume's Dialogues." Philosophical Quarterly 28: 300-309.

Vink, A. G. 1986. “The Literary and Dramatic Character of Hume's Dialogues Concerning Natural Religion.” Religious Studies 22 (3-4): 387-396.

Wieand, Jeffery. 1985. "Pamphilus in Hume's Dialogues." The Journal of Religion 65 (1): 33-45. 